\title{
An Uncommon Clinical Case with Fanconi Syndrome, Acanthosis Nigricans and Hyperinsulinemia
}

\author{
Yusuf Karadeniz ${ }^{\mathrm{a}}$, Suleyman Ahbab ${ }^{\mathrm{a}, \mathrm{b}}$, Abdulkadir Celik ${ }^{\mathrm{a}}$, Fatih Turker ${ }^{\mathrm{a}}$, \\ Recep Ayhan ${ }^{\mathrm{a}}$, Ali Atay ${ }^{\mathrm{a}}$
}

\begin{abstract}
Fanconi syndrome (FS) is a disease of the proximal renal tubules of the kidney in which glucose, amino acids, uric acid, phosphate, and bicarbonate are passed into the urine, instead of being reabsorbed. Laboratory findings are important for the diagnosis such as hyponatremia, hypopotassemia, hypocalcemia, hypophosphatemia, glucosuria, proteinuria, and metabolic acidosis. In this presentation, the patient admitted to the hospital with polyuria, polydypsia, weakness of the extremity muscles, and axiller brown colored cutaneous lesions. Blood and urine laboratory test results were consistent with FS. Besides, hyperglycemia and hyperinsulinemia were determined as an indicator of diabetes mellitus. Axillary skin lesions were described as acanthosis nigricans. This case was presented to point out the coexistence of renal proximal tubule dysfunction, hyperinsulinemia, and acanthosis nigricans as an unusual clinical feature in the literature.
\end{abstract}

Keywords: Fanconi syndrome; Acanthosis nigricans; Hyperinsulinemia

\section{Introduction}

Fanconi syndrome (FS) is a renal proximal tubule disorder which includes serum and urine electrolyte imbalance [1]. FS is characterized by clinical features such as growth retardation, muscle weakness, polyuria, and polydypsia and laboratory findings as aminoaciduria, glucosuria, calciuria, metabolic acidosis, hypocalcemia, hypophosphatemia, and hypopotassemia. Common causes of FS are cystinosis in children and multiple myeloma in adults. Other causes are Wilson's disease, Lowe syndrome, tyrosinemia, galactosemia, and glycogen storage disease, some antibiotic and antiviral drugs (tetracycline and tenofovir). Growth retardation and rickets are common in the course of FS [2]. Treatment of FS includes fluid and electrolyte replacement.

Acanthosis nigricans is a hyperpigmented, hyperkeratotic skin lesions which associated with insulin resistance, diabetes mellitus, and obesity. Lesions localized especially on axillary and inguinal areas. In this presentation, the coexistence of FS, acanthosis nigricans, and hyperinsulinemia in a male case is demonstrated.

\section{Case Report}

A 24 years old male patient, admitted to the hospital with complaints such as polyuria, polydypsia (approximately $8 \mathrm{~L} /$ day), proximal muscle weakness, for 3 months. Patient's history did not show any apparent chronic illness. There was a growth retardation compared to other family members, with height of $152 \mathrm{~cm}$ and weight of $56 \mathrm{~kg}$. Cardiovascular, respiratory, gastrointestinal, and neurological examination findings were normal. There were cutaneous lesions on axillary area which were brown colored and slightly raised from the skin. Cutaneous lesion was consulted with dermatology phy-

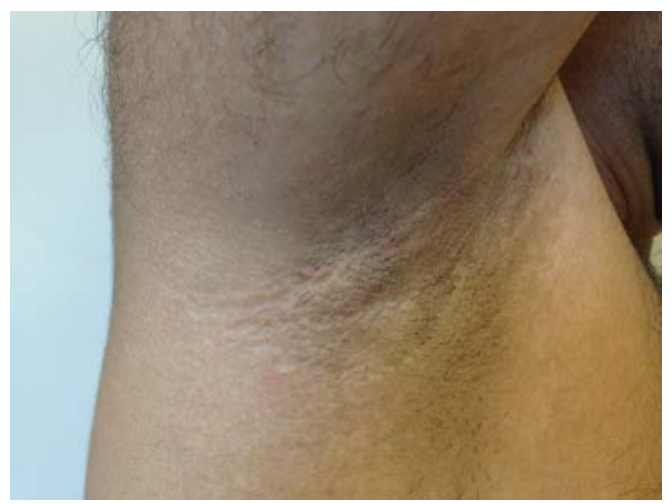

Figure 1. Axillary, brown colored skin lesion as acanthosis nigricans.

${ }^{a}$ Haseki Training and Research Hospital, Internal Medicine Clinic, Istanbul, Turkey

${ }^{\mathrm{b}}$ Corresponding author: Suleyman Ahbab, Haseki Training and Research Hospital, Internal Medicine Clinic, PK 34096, Fatih, Istanbul, Turkey. Email: drsahbab@hotmail.com 
Table 1. Initial Analysis of the Patient's 24 Hours Collected Urine Analysis Results

\begin{tabular}{lll}
\hline Parameters & Analyis results & Normal range \\
\hline Amount (mL/day) & 8,400 & $1,000-2,500$ \\
Creatinine clearence $(\mathrm{mL} / \mathrm{min})$ & 60.71 & $85-130$ \\
Calcium $(\mathrm{mg})$ & 871.92 & $100-300$ \\
Phosphate $(\mathrm{mg})$ & $1,375.64$ & $400-1,300$ \\
Magnesium $(\mathrm{mg})$ & 193.25 & $72-122$ \\
Sodium $(\mathrm{mmol})$ & 579.66 & $40-220$ \\
Potassium (mmol) & 79.81 & $25-125$ \\
Chloride $(\mathrm{mmol})$ & 520.72 & $110-250$ \\
Protein $(\mathrm{mg})$ & 982.89 & $30-150$ \\
Glucose (mg/dL) & 518 & 0 \\
\hline
\end{tabular}

sician and decided as acanthosis nigricans (Fig. 1). Bilateral lower joint muscle weakness was observed. Blood and urine laboratory tests were performed and hypopotassemia, hypocalcemia, and hypophosphatemia were observed as follows: fasting blood glucose $150 \mathrm{mg} / \mathrm{dL}$, urea $27 \mathrm{mg} / \mathrm{dL}$, creatinine $1.1 \mathrm{mg} / \mathrm{dL}$, sodium $130 \mathrm{mmol} / \mathrm{L}$ (135-148), potassium 2.91 $\mathrm{mmol} / \mathrm{L}$ (3.5-5.0), calcium $8.43 \mathrm{mg} / \mathrm{dL}(8.80-10.6)$, and phosphate $2.4 \mathrm{mg} / \mathrm{dL}$ (2.6-4.8). The 25-hydroxy vitamin D level was below normal $(<10 \mathrm{nmol} / \mathrm{L})$ and parathormon level was $83 \mathrm{pg} / \mathrm{mL}$ (12-68). These results were pointed out osteomalacia. Thyroid function tests, liver enzymes, sedimentation, cortisol, and hepatitis markers were between normal ranges. Radiological investigations, such as chest X-ray, direct abdominal graph, and abdominal ultra-sound graph, were normal. Urine analysis was carried out and proteinuria (982 mg/day), hypercalciuria, natriuresis, and glucosuria were determined (Table 1). Also, artery blood gas analysis displayed metabolic acidosis ( $\mathrm{pH}$ 7.29). These findings were consulted with nephrology department and diagnosed as FS (proximal renal tubule dysfunction). Because of the acanthosis nigricans, insulin level was measured and hyperinsulinemia was determined; fasting insulin $593.20 \mu \mathrm{U} /$ $\mathrm{mL}$, fasting C-peptide $23.91 \mathrm{ng} / \mathrm{mL}$. Thereafter, as a therapy, parenteral fluid treatment was performed and electrolyte disturbances were replaced with sodium chloride, sodium bicarbonate (anti-acidosis), potassium, and calcium. Besides, vitamin $\mathrm{D}$ added to the treatment. Metformin treatment ( 850 $\mathrm{mg} /$ day) was administered due to hyperinsulinemia. Polyuria and polydypsia were improved by the treatment. After 4 weeks, plasma insulin $(11.61 \mu \mathrm{U} / \mathrm{mL})$, C-peptide $(5.14 \mathrm{ng} /$ $\mathrm{mL})$, plasma electrolytes, and vitamin $\mathrm{D}(51.75 \mathrm{nmol} / \mathrm{L}) \mathrm{lev}$ els are normal, under the treatment.

\section{Discussion}

FS occurs as a result of functional impairment in renal proximal tubule cells. Renal proximal tubulus is responsible for reabsorption of filtrated solid plasma elements from glomerulus. Clinical findings are polyuria, polydypsia, and dehydration [3]. Laboratory findings are glucosuria, aminoaciduria, phosphaturia, bicarbonaturia, renal tubular acidosis, hyponatremia, hypopotassemia, hypercalciuria, and metabolic acidosis which are characteristic features of the disease. Electrolyte imbalance can yield to weakness of muscles. Osteomalacia and growth retardation can be seen, in the course of disease [4]. Hyperphosphaturia and hypercalciuria cause osteomalacia due to decreased hydroxylation of 25 -hydroxy vitamin D in proximal tubulus. In this presentation, after electrolyte imbalance was replaced and vitamin D was administrated, clinical improvement was provided.

Etiology of FS includes various causes such as inherited disease (glycogen storage disease, cystinosis, and tyrosinemia), idiopathic, exposure to heavy metals, Wilson's disease, kidney transplant, amiloidosis, antiviral therapy (tenofovir and cidofovir), and multiple myeloma [5-7]. A detailed etiolgical investigation and differential diagnosis was performed for this case. Any pathologic cause and inherited disorder were not determined. It was diagnosed as an idiopathic FS.

Acanthosis nigricans is described as a benign skin lesion which is characterized by brown-dark in color, hyperpigmented, hyperkeratotic plaques [8]. Lesion is localized on neck, axillary and inguinal areas, especially. It is associated with insulin resistance, obesity, malignancy, and diabetes mellitus [9]. In this case, axillary acanthosis nigricans was 
described and hyperinsulinemia with suspect type II diabetes mellitus was identified by laboratory findings. By the way, metformin treatment was applied and clinical recovery was provided. As a result, coexistence of FS with hyperinsulinemia and acanthosis nigricans in a case is unusual and unexpected disease combination, according to the literature.

\section{References}

1. Rohfleisch A, Nseir G, Chehade H, Noverraz MG, Venetz JP, Barbey F. [Renal glucosuria]. Rev Med Suisse. 2013;9(378):636-640.

2. Verhelst D, Monge M, Meynard JL, Fouqueray B, Mougenot B, Girard PM, Ronco P, et al. Fanconi syndrome and renal failure induced by tenofovir: a first case report. Am J Kidney Dis. 2002;40(6):1331-1333.

3. Norden AG, Lapsley M, Lee PJ, Pusey CD, Scheinman SJ, Tam FW, Thakker RV, et al. Glomerular protein sieving and implications for renal failure in Fanconi syndrome. Kidney Int. 2001;60(5):1885-1892.

4. Patra S, Nadri G, Chowdhary H, Pemde HK, Singh V, Chandra J. Idiopathic Fanconi's syndrome with neph- rogenic diabetes insipidus in a child who presented as vitamin D resistant rickets--a case report and review of literature. J Pediatr Endocrinol Metab. 2011;24(910):755-757.

5. Gracey DM, Snelling P, McKenzie P, Strasser SI. Tenofovir-associated Fanconi syndrome in patients with chronic hepatitis B monoinfection. Antivir Ther. 2013.

6. Selvan C, Thukral A, Chakraborthy PP, Bhattacharya R, Roy A, Goswani S, Meher D, et al. Refractory rickets due to Fanconi's Syndrome secondary to Wilson's disease. Indian J Endocrinol Metab. 2012;16(Suppl 2):S399-401.

7. Bhutani M, Klein MJ, Glezerman I, Landau H, Rosenzweig M, Hassoun H. Osteomalacia due to adult Fanconi syndrome in multiple myeloma. Leuk Lymphoma. 2011;52(3):536-538.

8. Schwartz RA. Keratoacanthoma. J Am Acad Dermatol. 1994;30(1):1-19; quiz 20-12.

9. Rafalson L, Pham TH, Willi SM, Marcus M, Jessup A, Baranowski T. The association between acanthosis nigricans and dysglycemia in an ethnically diverse group of eighth grade students. Obesity (Silver Spring). 2013;21(3):E328-333. 